\title{
Study of the properties of nanomaterials
}

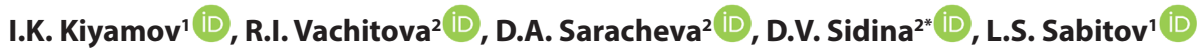 \\ ${ }^{1}$ Engineering Institute, Kazan (Volga Region) Federal University, Kazan, the Russian Federation; \\ ${ }^{2}$ Almetyevsk State Oil Institute, Almetyevsk, the Russian Federation \\ *Corresponding author: daria-mazankina@yandex.ru \\ (c) Authors, 2020
}

\begin{abstract}
To improve physical and mechanical properties of pavements new materials with nanomodified additives are being actively developed. The authors are investigating the properties of road petroleum bitumen with nanomaterial Taunit.

At the initial stage, oil bitumen was heated to $100^{\circ} \mathrm{C}$. Then carbon nanomaterial «Taunit» was added. After that, the mixture was stirred in an ultrasonic homogenizer until even distribution of the carbon nanomaterial in the total volume. The process of cooling of the final structure was carried out until the end of the crystallization process. Then, the specimens are exposed to tension and strength tests with a constant rate of deformation or loading until the moment of rupture on the testing machines. Mixing with other components of asphalt concrete in the standard mode follows the nanomodification of the bituminous mixture.

Under increased temperatures the bitumen mixture keeps properties of an effective binder. It was revealed that the modified carbon bitumen has good thermal properties, namely, it has a higher softening temperature ( $\Delta \mathrm{t}$ is in the range from 6 to $10^{\circ} \mathrm{C}$ ). The indicator, which indirectly characterizes the degree of hardness of bitumen solutions, is within the limits of GOST standards, decreases by $15-20 \%$.
\end{abstract}

KEYWORDS: pavement, oil bitumen, Taunit nanomaterial, adhesion.

FOR CITATION: Kiyamov I.K., Vachitova R.I., Saracheva D.A., Sidina D.V., Sabitov L.S. Study of the properties of nanomaterials. Nanotechnologies in Construction. 2020, Vol. 12, no. 2, pp. 65-70. DOI: 10.15828/2075-8545-2020-12-2-65-70.

\section{INTRODUCTION}

A $t$ the present stage, research in the country on the study of nanotechnology is in demand and is actively supported by the government of the Russian Federation, and is on the list of priority tasks for the development of technology and science. In Tatarstan, considerable attention is paid to the creation of new types of products modified by nanotubes. Scientific interest at the practical level is the improvement of the operational properties of pavements based on the modification of bitumen with the addition of carbon nanotubes for the production of the required export-oriented and import-substituting products [1-3].

The ever-increasing fleet of vehicles requires good quality roads. However, at present, we often face the problem of poor-quality repair of the roadbed, which is being carried out everywhere due to the poor quality of raw materials for the manufacture of road surfaces. The upper wear layer periodically is renewed as it wears out and determines the operational properties of the pavement [4-9].
The roadbed of roads includes the following components:

- oil road bitumen, which is a cementitious material and the basis for the development of nanomodified bitumen;

- slag crushed stone;

- sand of the required size modulus;

- finely dispersed mineral powder, which imparts strength properties to the roadbed.

For the construction of high quality roads, the quality of raw materials, namely the quality of bitumen, is important [10]. Bitumens are resinous or solid substances that are a mixture of hydrocarbon fractions and their metalcontaining, nitrogenous, oxygen and sulfur derivatives.

\section{MAIN PART}

The development of building complexes determines a high level of demand for bitumen, forcing producers to produce bitumen from oils of various qualities, sometimes not suitable for this. Such road bitumen is characterized 
by low adhesive, physical, mechanical and operational properties. The priority issues are the quality of the roadway, provided by increasing the strength characteristics of the adhesive bond between the mineral filler and oil bitumen, since this indicator plays a decisive role in maintaining the integrity of the road surface [11-14].

The decisive characteristic of petroleum bitumen is adhesion, which characterizes the ability of road bitumen to adhere to the remaining component particles of the asphalt mix. In the case of poor adhesion, sand and gravel are detached from petroleum bitumen and the road surface begins to crumble.

Thermotechnical characteristics of road bitumen are also important. Thermotechnical characteristics of materials include the following properties: softening temperature, flash point, fire resistance, heat capacity, brittleness temperature, thermal conductivity, etc.

The marking sign of viscous road bitumen, which indirectly determines the viscosity, is the penetration value, determined by the depth of penetration of the needle into the bitumen mixture at temperatures of 25 and $0^{\circ} \mathrm{C}$. The penetration depth of the needle depends on the content of a sphaltenes in oil bitumen and characterizes the performance properties of bitumen, namely strength, heat resistance and hardness.

The softening temperature of petroleum bitumen characterizes the process of changing the viscosity component of bitumen with temperature. This indicator is determined by the "Ring and Ball" method, that is, the temperature is determined at which the oil bitumen located in the ring with the given dimensions softens during the test and, moving under the influence of a metal ball, touches the lower part of the plate, at this time the softening temperature is fixed. Bitumen in the molten state is poured into a copper ring, which is placed on a glass plate impregnated with talc. A ball is placed on a copper ring with a bitumen mixture and, together with a thermometric device, is placed in a container of water. For a ball and a ring, in each case, the temperature value is determined at which the bitumen extruded by the steel ball touches the lower plate. When the ball presses through the bitumen, the test is repeated. In the case of a repeated test, the bursting is repeated. Experimental measurements are carried out in accordance with GOST 11506-73.

The fragility temperature is characterized by the temperature of the destruction of oil bitumen under the action of a short-term force.

The flash point is characterized by the lowest temperature when oil bitumen vapors can flare up when a fire source is brought to it above its surface. This indicator characterizes the level of flammability of bitumen in case of its heating.

All these characteristics must meet the requirements of state industry standards [15]. When these indicators deviate from regulatory requirements, roads quickly become unusable, which requires large financial costs for the restoration and repair of pavements.

To solve the indicated problem, fundamental research is actively carried out using nanomodified materials. Such materials are obtained by adding particles with very small sizes of about a few nano- and micrometers to traditional materials in order to improve the required characteristics and properties of materials [16-19]. There are many different types of nano-additives. It is proposed to use bitumen composite nanomodified materials, namely carbon nanotubes. Carbon nanotubes can be represented as an extended cylindrical structure having a diameter of several tens of nanometers and a length of several centimeters. There are technologies that allow you to weave nanotubes in the form of filaments of unlimited length. They may look like one or several tubular rolled graphene planes with a hemispherical head at the end, and considered as part of a fullerene molecule [20-25]. At present, the mechanism of fullerene formation has not been established. There is an assumption that fullerenes appear from carbon atoms, which are connected to each other in a layer consisting of sixmembered benzene articulated rings, then at a certain moment the layer is folded into a polyhedron. The image of nanotubes is shown in Fig. 1.

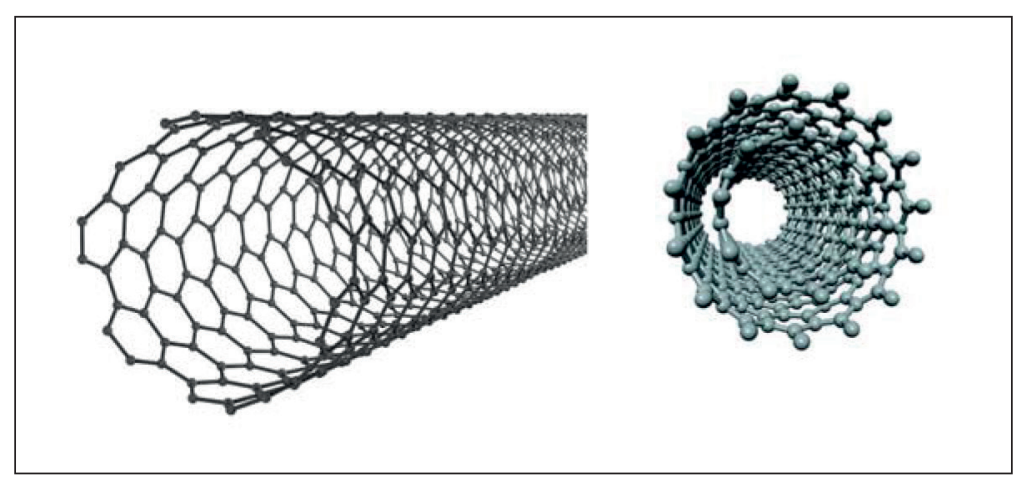

Fig. 1. Image of nanotubes 
STUDY OF PROPERTIES OF NANOMATERIALS

Table 1

Parameters of carbon nanomaterial "Taunit"

\begin{tabular}{|c|c|c|c|c|c|}
\hline \multirow{2}{*}{$\begin{array}{c}\text { Carbon } \\
\text { nanomaterial }\end{array}$} & \multicolumn{5}{|c|}{ Characteristics } \\
\hline & $\begin{array}{c}\text { Inner diameter, } \\
\mathrm{nm}\end{array}$ & $\begin{array}{c}\text { Outside } \\
\text { diameter, } \mathrm{nm}\end{array}$ & Length, mcm & $\begin{array}{l}\text { Specific geometri- } \\
\text { cal surface, } \mathrm{m}^{2} / \mathrm{g}\end{array}$ & $\begin{array}{l}\text { Bulk density } \\
\mathrm{g} / \mathrm{cm}^{3}\end{array}$ \\
\hline Taunit & $5-10$ & $20-70$ & 2 and more & 120 and more & $0.4-0.6$ \\
\hline Taunit - MD & $4-8$ & $8-15$ & 2 and more & 300 and more & $0.03-0.05$ \\
\hline Taunit M & $10-20$ & $30-80$ & 20 and more & $180-200$ & $0.03-0.05$ \\
\hline
\end{tabular}

\section{RESULT AND DISCUSSION}

For the production of asphalt mix, bitumen of the BND 90/130 variety is used (the depth of penetration of a needle with a thickness of $0.1 \mathrm{~mm}$ at a temperature of $250^{\circ} \mathrm{C}$ is in the range from 91 to $130 \mathrm{~mm}$ ). The component "Taunit" was chosen as a carbon nanodditive [26]. This component is a multilayer stacked nanotube, mainly conical in the form of graphene layers. The total amount of impurities in the Taunit product is within 1\%, and its thermal stability is up to $6000^{\circ} \mathrm{C}$. Table 1 presents the parameters of carbon nanomaterial "Taunit".

To study the physical structure and properties of nanomaterials, we used equipment of the Center for Nanotechnology RT LLC (Kazan). The micrometer sizes of carbon nanomaterial granules are a structure in the form of tangled bundles of carbon multi-walled nanotubes. The microstructures of the Taunit material were investigated. For this purpose, a high-resolution Merlin electronic field emission scanning microscope manufactured by CARL ZEISS was used. This microscope is used to measure microrelief linear dimensions in various structures. The image under the microscope of the Taunit nanomaterial is shown in Fig. 2.

Studies were carried out in a certain sequence. At the initial stage, oil bitumen was heated to $100^{\circ} \mathrm{C}$. Next, Taunit carbon nanomaterial was added to the heated mixture. The volume of carbon nanomaterial that is introduced into the mixture is in the range of $0.01-0.005 \%$ of the mass amount of bitumen. After that, this mixture was mixed in an ultrasonic homogenizer until the carbon nanomaterial was evenly distributed in the total volume. The ultrasonic homogenization process is especially effective for grinding hard and soft particles. This process is based on the application of the action of cavitation, when the studied liquids are subjected to sufficiently intense action of sound waves, the process is characterized by the appearance of alternating low and high pressure cycles (about 20,000 cycles per second). At low pressure, small vacuum bubbles form. When the bubbles reach a certain size during the period of high pressure, they instantly collapse. The high velocity and high pressure of the liquid jet are generated locally during an internal explosion, and the turbulence and the resulting flows break apart

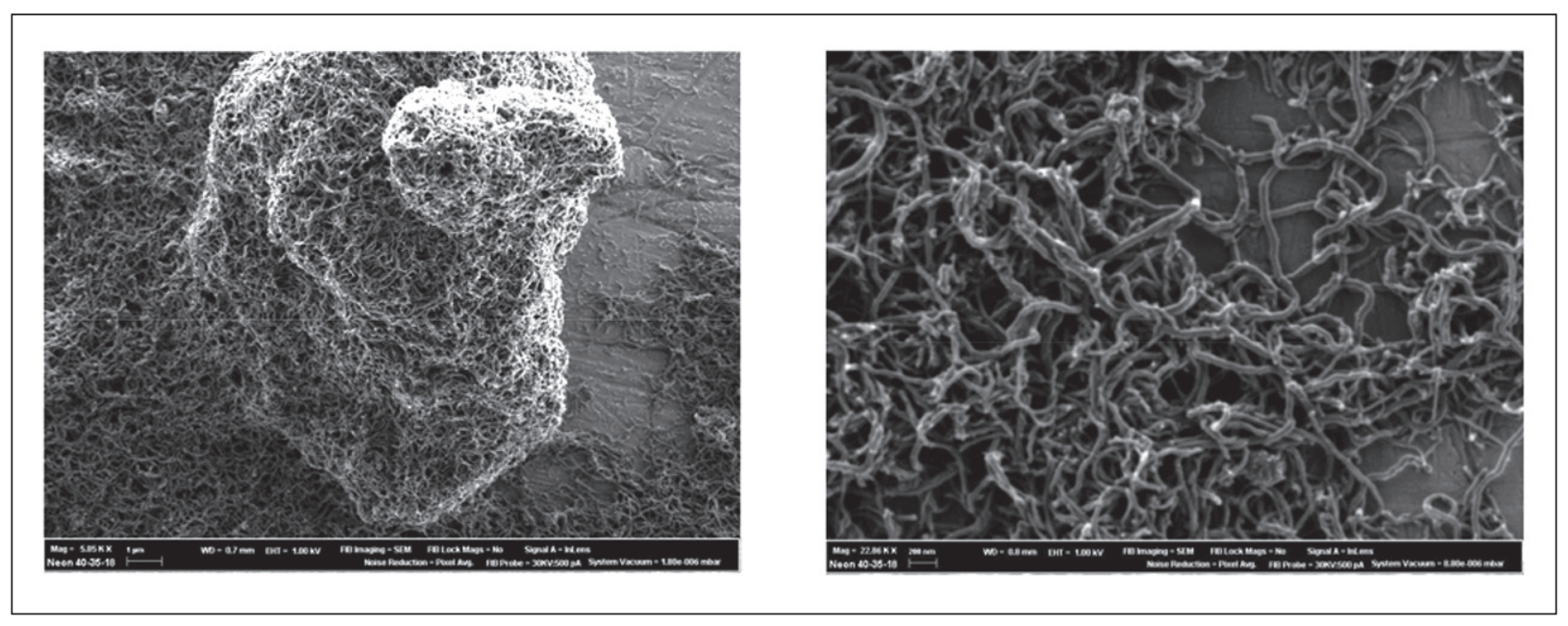

Fig. 2. Taunit nanomaterial under a microscope 
the particles and contribute to strong collisions between the individual particles. The cooling process of the resulting structure was carried out until the end of the crystallization process. Then, control samples were tested for tensile strength and at a constant rate of deformation or loading up to the moment of rupture on testing machines. Mixing with other components of asphalt concrete in the standard mode occurs after the nanomodification of the bitumen mixture.

As a result of the experiments, it was found that the addition of a nanomodifier to the bitumen solution significantly increases the elasticity and strength of the resulting asphalt sheet. The following was established: even insignificant mass additives (up to $0.005 \%$ ) of carbon nanomaterials increase the compressive strength of the bitumen mixture. These characteristics were determined by the depth of indentation of the stamp element into the test samples.

We also studied the physical and mechanical properties of bitumen samples with modified carbon nanomaterials, namely, the softening temperature by the Ring and Ball method and the penetration depth of the needle by penetration. These properties make it possible to use nanomodified bitumen as part of the asphalt mix in regions with hot climatic conditions. As a result of the re- search, it was found that the modified carbon bitumen mixture had improved thermotechnical properties, as it had a sufficiently high softening temperature. The indicator indirectly characterizing the level of hardness of bitumen mixtures, namely, the penetration index, was within acceptable limits in accordance with GOST standards [1].

Studies show that even a small amount of carbon nanomaterial can improve the strength characteristics of a bitumen mixture, such as ductility, adhesive properties and durability. There is a need to study the effect of nanostructured and polymer modifiers in the complex on the strength characteristics of petroleum bitumen [2].

\section{CONCLUSION}

Under increased temperatures the bitumen mixture keeps the properties of an effective binder material, and, as a result, high-quality operational parameters are preserved. It was revealed that the modified carbon bitumen has good heat engineering properties, namely, it has a higher softening temperature $(\Delta t$ is in the range from 6 to $10^{\circ} \mathrm{C}$ ). The indicator, which indirectly characterizes the degree of hardness of bitumen solutions (penetration indicator), is within the standards of GOST, and sometimes it decreases by $15-20 \%$.

\section{REFERENCES}

1. Guz A.N., Rushchitskii Y.Y. (2003) Nanomaterials: on the mechanics of nanomaterials. International applied mechanics. 39. pp. 1271-1293. DOI: 10.1023/B:INAM.0000015598.53063.26.

2. Kemalov A.F., Kemalov R.A., Kostromin R.N., Mullakhmetov N.R. (2010) Razrabotka modifikatorov k dorozhnym bitumam [Development of modifiers for road bitumen]. Vestnik Kazanskogo tekhnologicheskogo universiteta. 7. pp. 469-470. (In Russian).

3. Kolesnikov G.N., Gavrilov T.A. (2018) Modelirovaniye usloviy poyavleniya nizkotemperaturnykh treshchin v asfal'tobetonnom sloye avtomobil'noy dorogi [Simulation of the conditions for a lowtemperature crack appearance in the asphalt concrete layer of a road]. Vestnik Tomskogo gosudarstvennogouniversiteta. Matematika i mekhanika [Tomsk State University Journal of Mathematics and Mechanics]. 56. pp. 57-66. DOI 10.17223/19988621/56/5 (In Russian).

4. Gureyev A.A., Bystrov N.V. (2013) Dorozhnyye bitumy - vchera, segodnya, zavtra [Road bitumens - yesterday, today, tomorrow]. Neftepererabotka i neftekhimiya. Nauchno-tekhnicheskiye dostizheniya i peredovoy opyt. 5. pp. 3-6. (In Russian).

5. Vapayev M. D., Bobarazhabov B., Teshabayeva E.U., Ibadullayev A. (2018) Dorozhnyye kompozitsii na osnove modifitsirovannykh bitumov [Road compositions based on modified bitumen]. Khimiya i khimicheskaya tekhnologiya. 4. pp. 46-48. (In Russian).

6. Nguyen thu Huong, Nguyen the Long, Sidorov D.N. A robust approach for road pavement defects detection and classification. Journal of computational and engineering mathematics. 2016. Vol. 3. No. 3. Pp. 40-52. DOI: 10.14529/jcem160305.

7. Zhao Q., Cherg P., Wang J., Wei YU. Damage prediction model for concrete pavements in seasonally frozen regions. Magazine of Civil Engineering. 2018. No. 8. Pp. 57-66. DOI: 10.18720/MCE.84.6.

8. Zavyalov M.A., Kirillov A.M. Evaluation methods of asphalt pavement service life. Magazine of Civil Engineering. 2017. No. 2. Pp. 42-56. DOI: 10.18720/MCE.70.5.

9. Shekhovtsova S. Yu., Korolev E.V., Inozemtcev S.S., Yu J., Yu H. Methods of forecasting the strength and thermal sensitive asphalt concrete. Magazine of Civil Engineering. 2019. No. 5. Pp. 129-140. DOI: 10.18720/MCE.89.11. 
STUDY OF PROPERTIES OF NANOMATERIALS

10. Khudyakova T.S. (2008) O normativnykh trebovaniyakh k dorozhnomu bitumu kak materialu tselevogo naznacheniya [On regulatory requirements for road bitumen as a target material]. Vestnik Khar'kovskogo natsional'nogo avtomobil'no-dorozhnogo universiteta. 40. Pp. 21-24. (In Russian).

11. Kemalov A.F., Kemalov R.A. (2011) Sovremennyye innovatsionnyye tekhnologii v proizvodstve bitumov i bitumnykh materialov [Modern innovative technologies in the production of bitumen and bitumen materials]. Neft'. Gaz. Novatsii. 10. Pp. 68-79. (In Russian).

12. Mullakhmetov N.R., Kemalov A.F., Kemalov R.A., Kostromin R.N. (2010) Modifikatsiya dorozhnykh bitumov kauchukom [Modification of road bitumen with rubber]. Vestnik KNITU. 7. Pp. 467-468. (In Russian).

13. Ayupov D.A., Murafa A.V., Khakimullin Yu.N., Makarov D.B., Gaynullin I. R. (2015) Reaktsionnosposobnyye polimernyye modifikatory bituma [Reactive polymer modifiers of bitumen]. Materialy Mezhdunarodnoy nauchno-prakticheskoy konferentsii, posvyashchennoy 95-letiyu FGBOU VPO «GGNTU im. akad. M.D. Millionshchikova». Federal'noye gosudarstvennoye byudzhetnoye obrazovatel'noye uchrezhdeniye vysshego professional'nogo obrazovaniya «Groznenskiy gosudarstvennyy neftyanoy tekhnicheskiy universitet imeni akademika M.D. Millionshchikova» (FGBOU VPO «GGNTU»). Pp. 295-301. (In Russian).

14. Shiryayev A.O., Obukhov A.G., Vysotskaya M.A., Shekhovtseva S.YU. (2017) Polimernyye modifiatory bitumnykh vyazhushchikh [Polymeric modifiers of bitumen binders]. Vestnik Belgorodskogo gosudarstvennogo universiteta im. V.G. Shukhova. 11. Pp. 48-54. (In Russian).

15. GOST 22245-90 (1996). Bitumy neftyanyye dorozhnyye vyazkiye. Tekhnicheskiye usloviya [SEST 22245-90. Bitumens oil road viscous. Technical conditions]. Moscow: Izd-vo standartov. (In Russian).

16. Khussein S.M. R. Kh., Hanfar A. (2017) Uglerodnyye nanotrubki: problemy i perspektivy ikh ispol'zovaniya [Carbon nanotubes: problems and prospects for their use]. Uspekhi sovremennoy nauki. 4. Pp. 166-169. (In Russian).

17. László I., Gyimesi B., Koltai J., Kürti J. (2017) Molecular dynamics simulation of carbon structures inside small diameter carbon nanotubes. Physica Status Solidi (B): Basic Solid State Physics. 254. Pp. 170-206.

18. Lebedeva O.S., Lebedev N.G.,Lyapkosova I.A. Piezoconductivity of chiral carbon nanotubes in the framework of the tight-binding method. Mathematical physics and computer simulation. 2018. Vol. 21. No. 1. Pp. 53-63. DOI: 10.15688/mpcm. jvolsu.2018.1.6.

19. Bryantsev Ya.A., Arhipov V.E., Romanenko A.I., Berdinsky A.S., Okotrub A.V. Control conductance of single walled carbon nanotubes films during synthesis. Magazine of the Siberian Federal University. Series: Mathematics and Physics. 2018. Vol. 11. No. 2. Pp. 222-226. DOI: 10.17516/1997-1397-2018-11-2-222-226.

20. Detlef B., Klaus S. (2009) Chemomechanical processing - the innovative way of integrating nanoparticles into industrial products. PETROTECH. India: New Delhi. Pp. 286.

21. Shah K.A., Najar F.A., Andrabi S.M.A., Islam S.S. (2017) Synthesis of carbon nanotubes for device applications. Asian Journal of Chemistry. 29. Pp. 879-881.

22. Danoglidis P.A., Falara M.G., Maglogianni M., Konsta-Gdoutos M.S. Scalable processing of cementitious composites reinforced with carbon nanotubes (CNTs) and carbon nanofibers (CNFs). Nanotehnologii v stroitel'stve $=$ Nanotechnologies in Construction. 2019, Vol. 11, no. 1, pp. 20-27. DOI: 10.15828/2075-8545-2019-11-1-20-27.

23. Dyachkova T.P., Rukhov A.V., Tkachev A.G., Tugolukov E.N. Functionalization of carbon nanotubes: methods, mechanisms and technological realization. Advanced materials sand technologies. 2018. No. 2. Pp. 18-41. DOI: 10.17277/amt.2018.02.pp.018-041.

24. Dyachkova T.P., Rukhov A.V., Tugolukov E.N., Usol'tseva N.V., Khan Yu.A., Chapaksov N.A. Studying of structural changes of grapheme layers of carbon nanotubes functionalized by raman spectroscopy. Liquid crystals and their practical use. 2017. Vol. 17. No. 4. Pp. 83-89. DOI: 10.18083/LCAppl.2017.4.83.

25. Kulnitskiy B.A., Blank V.D. Iron carbide formation inside carbon nanotubes. Advanced materials sand technologies. 2017. No. 3. Pp. 34-39. DOI: 10.17277/amt.2017.03.pp.034-039.

26. Simagin D.N., Gravin A.A., Kulakov V.Yu.,Litovka Yu.V., Dyakov E.A. The effect of taunit carbon nanotubes on the properties of electroplating and anodic oxide coatings. Advanced materials sand technologies. 2016. No. 2. Pp. 35-42. DOI: 10.17277/ amt.2016.02.pp.035-042. 


\section{INFORMATION ABOUT THE AUTHORS}

Ilgam K. Kiyamov, Doctor of Economics, Professor, Engineering Institute, Department of Biomedical Engineering and Innovation Management, Kazan (Volga Region) Federal University; Kremlin st., 18, Kazan, Republic of Tatarstan, the Russian Federation, 420008, kiyamov.ilgam@mail.ru

Roza II. Vachitova, Camd. Sci. (Eng.), Associate Professor, Department «Electrical and Thermal Power Engineering», Almetyevsk State Oil Institute; Lenina st., 2a, Almetyevsk, Republic of Tatarstan, the Russian Federation, 423450, roza-w@mail.ru

Diana A. Saracheva, Camd. Sci. (Eng.), Senior Lecturer, Department «Electrical and Thermal Power Engineering», Almetyevsk State Oil Institute; Lenina st., 2a, Almetyevsk, Republic of Tatarstan, the Russian Federation, 423450, sarachevadiana85@mail.ru

Daria V. Sidina, Senior Lecturer, Department «Electrical and Heat Power Engineering», Almetyevsk State Oil Institute; Lenina st., 2a, Almetyevsk, Republic of Tatarstan, the Russian Federation, 423450, daria-mazankina@yandex.ru

Linar S. Sabitov, Camd. Sci. (Eng.), Senior Lecturer Department of Biomedical Engineering and Innovation Management, Engineering Institute, Kazan (Volga Region) Federal University, Kazan, the Russian Federation, Kremlin st., 18, Kazan, Republic of Tatarstan, the Russian Federation, 420008, sabitov-kgasu@mail.ru

Received: 05.03.2020.

Revised: 27.03.2020.

Accepted: 02.04.2020. 